Research Article

\title{
$\alpha$-Amilase Inhibitory Activity of Fraction of Ethanolic Extract of Lebui Seed (Cajanus cajan (L.) Millsp.) Grown in West Nusa Tenggara
}

Dian Resti Setyaningrum¹, Rumiyati ${ }^{1 *}$, ${ }^{1}$ Yekti Asih Purwestri², Satrijo Saloko ${ }^{3}$, Agung Endro Nugroho', Yudi Pranoto ${ }^{4}$, Sri Widyastuti ${ }^{3}$

${ }^{1}$ Faculty of Pharmacy, Universitas Gadjah Mada, Sekip Utara, Yogyakarta 55281 Indonesia

${ }^{2}$ Faculty of Biology Universitas Gadjah Mada, Jalan Teknika Selatan, Yogyakarta 55281 Indonesia

${ }^{3}$ Faculty of Food Technology and Agro Industry, University of Mataram, Nusa Tenggara 83126 Indonesia

${ }^{4}$ Faculty of Agriculture Technology Universitas Gadjah Mada, Jalan Flora, Yogyakarta 55281 Indonesia

*Corresponding author:Rumiyati | Email: rumiyaris@ugm.ac.id

Received: 8 August 2020; Revised: 22 August 2020; Accepted: 15 September 2020; Published: 26 October 2020

\begin{abstract}
Diabetes is a metabolic syndrome characterized by high blood sugar levels or hyperglycemia. Alpha-amylase inhibitors can be used as an antidiabetic that controls postprandial hyperglycemia. Alpha-amylase inhibitors are found in plants as protein and non-protein bioactive content such as in lebui seed. The purpose of this study was to determine the activity of alpha-amylase inhibition of the fraction of ethanol extract of lebui seed. This research was carried out by extraction of lebui seed and then fractionated lebui extract to obtain n-hexane fraction (HF), ethyl acetate fraction (EAF), and water fraction (WF). The fractions then tested to alpha-amylase inhibition activity in vitro by measuring the reducing sugar using 3.5-dinitrosalicylic (DNS) reagent. Furthermore, the identification of the bioactive content of each fraction was carried out using thin layer chromatography. The results of alpha-amylase inhibition activity test showed that all fractions had the ability to inhibit alpha-amylase. The $\mathrm{IC}_{50}$ value of the n-hexane fraction, ethyl acetate fraction, and water fraction were $173.05 \mathrm{mg} / \mathrm{ml}, 9.98 \mathrm{mg} / \mathrm{ml}$, and $137.19 \mathrm{mg} / \mathrm{ml}$, respectively. Ethyl acetate fraction has the smallest $\mathrm{IC}_{50}$ value compared to other fractions. Based on the identification of the bioactive content, bioactive content that is only found in the ethyl acetate fraction but not in other fractions are tannins. Therefore, the chemical content in lebui seed which acts as an alpha-amylase inhibitor might be tannins.
\end{abstract}

Keywords : lebui seeds (Cajanus cajan (L.) Millsp.); $\alpha$-amilase; fraction of ethanol extract

\section{INTRODUCTION}

Diabetes mellitus is a metabolic syndrome caused by the inability of the pancreas to produce insulin or the loss of the body's ability to effectively use insulin which causes hyperglycemia that can lead to various macrovascular and microvascular complications [1,2]. Based on data of IDF, in 2015 there were 415 million adults with diabetes. By 2040, this number is predicted to increase to 642 million people.

Treatment of diabetes mellitus aims to control the blood sugar levels of patients to minimize the risk of macrovascular and microvascular complications. $\alpha$-amylase inhibitors can inhibit the breakdown of carbohydrates to glucose so that glucose absorption decreases. $\alpha$-Amylase works to hydrolyze carbohydrates into oligosaccharides and dextrins which will be further hydrolyzed to glucose. Glucose will be absorbed by the intestinal epithelium and enter the 
bloodstream [3]. Therefore, inhibition of the $\alpha$-amylase enzyme can delay and prolong the digestion of carbohydrates so that the rate of absorption of glucose decreases and prevents the postprandial hyperglycemia [4].

Lebui seed (Cajanus cajan (L.) Millsp) is one of the 5 most important nuts in the world along with soybeans, peanuts, green beans and red beans. Protein extract of lebui seed has an $\alpha$-amylase inhibitor isoform which inhibits amylase in human saliva and bovine pancreas [5]. Besides protein, non-protein bioactive compounds from plants such as tannins, flavonoids, alkaloids, and terpenoids also have $\alpha$-amylase inhibitory activity [6-9]. Lebui seeds have known to contain flavonoids, tannins, alkaloids, saponins, cyanogenic glycosides, glycosides, and anthocyanins [10]. However, research on the inhibition activity of $\alpha$-amylase from the fraction of the lebui seed grown in West Nusa Tenggara and identification of the active content has not been done yet. Therefore this research is needed to obtain information about the $\alpha$-amylase inhibitory activity of bioactive compounds non-protein of the lebui seed.

\section{MATERIALS AND METHODS}

\subsection{Materials}

Porcine pancreas $\alpha$-amylase type VI-B (Sigma A-3176), 3,5-dinitrosalisilat acid (Sigma D-0550), soluble starch (Merck), glucobay tablet (Bayer), ethanol, aquadest, n-heksane, ethyl acetate, dragendorff reagent, amonia, $\mathrm{FeCl}_{3}$, Liebermann Burchard reagen, silica gel G60 F254 (Merck).

\subsection{Plant material}

Lebui (Cajanus cajan L. Millsp) seed was collected from Kebun Roek Traditional Market, North Ampenan, Mataram, West Nusa Tenggara. The lebui seed has been determinated in Biology Pharmacy Departement of Faculty of Pharmacy, Universitas Gadjah Mada.

\subsection{Preparation of plant extract}

Lebui seed was immediately washed by distilled water and dried in the oven at $50^{\circ} \mathrm{C}$. The dried sample was ground to a fine powder. The crude ethanolic extract was obtained by extracting $200 \mathrm{~g}$ of dried plant powder in $1.500 \mathrm{ml}$ ethanol and soaked for 48 hours. The extract was further concentrated using vacuum rotary evaporator at $50^{\circ} \mathrm{C}$ and stored in a refrigerator at $4-8^{\circ} \mathrm{C}$ until required.

\subsection{Preparation of Fraction of Plant Extract}

The fractionation of lebui seed extract was done using the liquid-liquid partition method. Fifteen grams of lebui seed extract was dispersed with $150 \mathrm{ml}$ warm aquadest. The extract then partitioned with $150 \mathrm{ml}$ of $\mathrm{n}$-hexane and the $\mathrm{n}$-hexane phase was taken. Repeat the step until a clear n-hexane phase is obtained. Furthermore, the extract was partitioned with $150 \mathrm{ml}$ of ethyl acetate and the ethyl acetate phase was taken. Repeat the step until a clear ethyl acetate phase is obtained. Each fraction includes n-hexane fraction, ethyl acetate fraction, and extract residue as water fraction were evaporated using vacuum rotary evaporator at $50^{\circ} \mathrm{C}$ and stored in a refrigerator at $4-8^{\circ} \mathrm{C}$ until required.

\section{5. $\alpha$-Amilase inhibitory activity of fraction of plant extract}

The method used for $\alpha$-amylase inhibition assay was a modification of McCue and Shetty (2004). The assay mixture containing $200 \mu \mathrm{L} \alpha$-amylase $2 \mathrm{U} / \mathrm{ml}$ in $0.02 \mathrm{M}$ sodium phosphate buffer, and $200 \mu \mathrm{L}$ fraction of lebui seed extract in concentration range of $10-200 \mathrm{mg} / \mathrm{ml}$, were incubated at $25^{\circ} \mathrm{C}$ for 10 minutes. Then, added $200 \mu \mathrm{L}$ of $1 \%$ starch in $0.02 \mathrm{M}$ sodium phosphate buffer and 
incubate for 10 minutes at $25^{\circ} \mathrm{C}$. The reaction was terminated with the addition of $800 \mu \mathrm{L}$ DNS reagent and placed in boiled water for 5 minutes. The reaction mixture was diluted with $4 \mathrm{ml}$ aquadest and the absorbance was measured at $540 \mathrm{~nm}$ using spectrophotometer. The control samples were prepared with the same procedure using $0.02 \mathrm{M}$ sodium phosphate buffer instead of fraction of lebui seed extract.

$$
\% \text { Inhibition }=\frac{(\text { Abs.control-Abs.sample })}{\text { Abs.control }} \times 100 \%
$$

The IC 50 value was determined from the regression equation of $\%$ Inhibition mean value vs concentration of the sample. Acarbose was used as the $\alpha$-amylase inhibitor reference. All tests were performed in triplicate.

\subsection{Analysis of bioactive compounds}

The identification of bioactive compounds was carried out using thin layer chromatography with silica gel as a stationary phase.

\subsubsection{Flavonoids}

The mobile phase used butanol: acetic acid: water (BAW) (4:1:5), with ammonia vapor as the detection reagent. Positive reactions are indicated by the formation of brown-yellow stains on visible and blue, and yellow observations on $366 \mathrm{~nm}$ UV light observations after ammonia was exposed [11,12].

2.6.2. Alkaloids

The mobile phase that used was methanol: $\mathrm{NH}_{4} \mathrm{OH}$ (100:3), with dragendorff as the detection reagent. A positive reaction is indicated by the formation of orange spots on visible-light observations after spraying dragendorff [12].

2.6.3. Tanin

The mobile phase that used was butanol: acetic acid: water (BAW) (4:1:5), with $\mathrm{FeCl} 3$ as the detection reagent. A positive reaction is indicated by the formation of blackish-blue spots after being sprayed with $\mathrm{FeCl}_{3}$ [13].

2.6.4. Triterpenoids and steroids

The mobile phase used was chloroform: methanol (9:1), with Liebermann-Burchard as the detection reagent. The positive reaction of terpenoid is shown by the formation of pink spots, magenta to purple after being sprayed by Liebermann-Burchard on visible-light [14]. Where as the positive results of triterpenoid are indicated by the presence of brown spots, and positive results of steroid are indicated by the presence of green or blue spots on visible-light observations [15].

\section{RESULTS AND DISCUSSION}

\subsection{Extraction and Fractionation}

The result of extraction using ethanol found that rendemen of lebui seed ethanolic extract was $7.29 \%$. While the rendemen of n-heksane fraction, ethyl acetate fraction, and water fraction were $16.64 \%$; $2.20 \%$; and $44.49 \%$, respectively.

\section{2. $\alpha$-Amilase inhibitory of plant extract fraction}

The $\alpha$-amylase inhibitory activity of lebui seed ethanolic extract, fraction of lebui seed ethanolic extract, and acarbose were investigated in this study and the results are shown in Figure 
1, Figure 2 and Table 1. Figure 1 shows $\%$ of the inhibition and then the value were changed to $\mathrm{IC}_{50}$ value such as summarized in table 1 . The results indicate that the lebui seed ethanolic extract and fraction of lebui seed ethanolic extract have the $\alpha$-amylase inhibitory activities, but no better than acarbose. Ethyl acetate fraction has the smallest IC 50 value of $9.9878 \mathrm{mg} / \mathrm{ml}$ which indicates it has the highest potential to inhibit $\alpha$-amylase activity than ethanolic extract and other fractions.

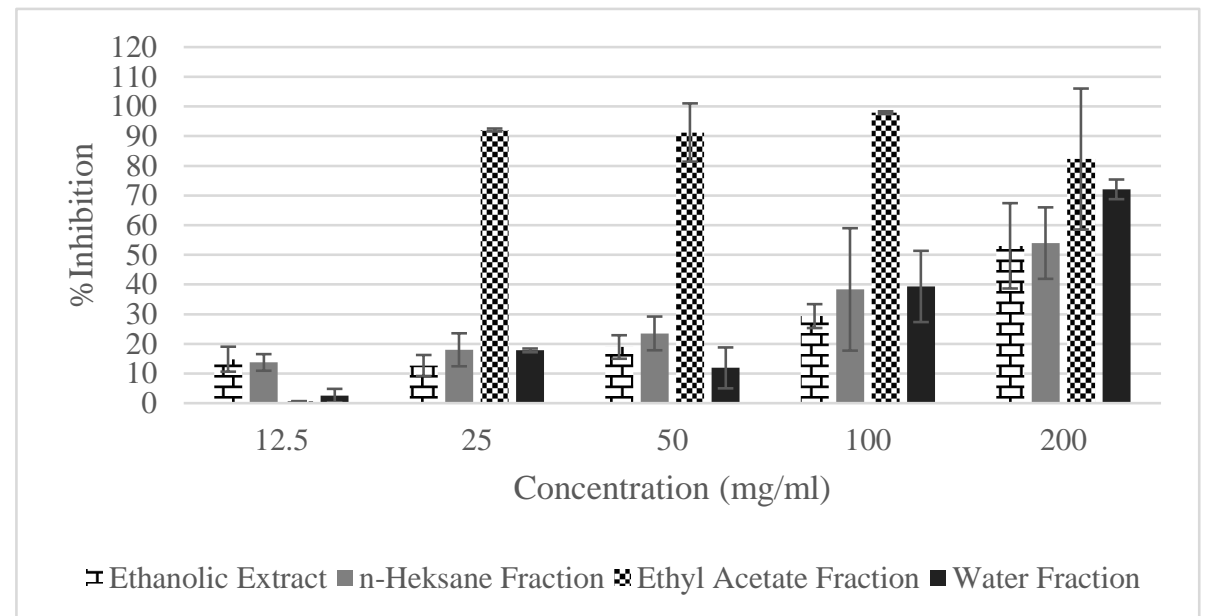

Figure 1. \% Inhibition value of fraction of lebui seed ethanolic extract (triplicate)

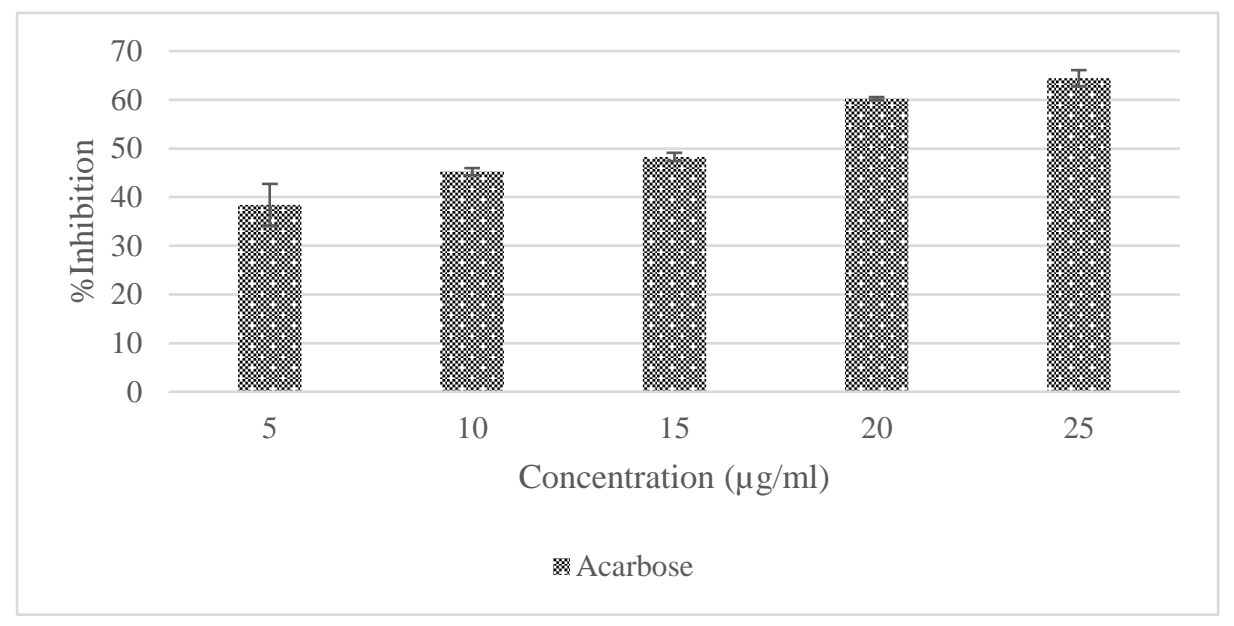

Figure 2. \% Inhibition value of acarbose (triplicate)

Table 1. IC50 value

\begin{tabular}{lr}
\hline \multicolumn{1}{c}{ Sample } & IC 50 ( $\mathbf{m g} / \mathbf{m l})$ \\
\hline Ethanolic extract & 190.0543 \\
n-Heksane fraction & 173.0489 \\
Ethyl acetate fraction & 9.9878 \\
Water fraction & 137.1920 \\
Acarbose & 0.0140 \\
\hline
\end{tabular}

\subsection{Analysis of bioactive compounds}

Analysis of bioactive compounds in this research aims to determine flavonoid, alkaloid, terpenoid, steroid and tannin compounds in the fraction and ethanol extract. In the identification of flavonoid compounds using thin layer chromatography, positive results were obtained on ethanol 
extract, ethyl acetate fraction and water fraction (Figure 3, no,1). It can be shown from appearance of spots after evaporated with ammonia in UV $366 \mathrm{~nm}$ with Rf 0.40 at E, Rf 0.56 in at EA, and 0.40 at A. Based on Markham (1988), analysis of the spots found that the spots are flavonoid. The possibility of type of the flavonoid is isoflavones which does not have 5-OH free. In addition, analysis using the UV $366 \mathrm{~nm}$ also found red-orange spots on Rf 0.64 in E, EA, and A which were suspected to be anthocyanin compounds.

The results of the identification of tannin compounds can be seen in Figure 3 no.2. Identification of tannin group compounds obtained positive results on EA as shown by the presence of black spots with Rf 0.93 in observations of visible light after spraying $\mathrm{FeCl}_{3}$ reagents.

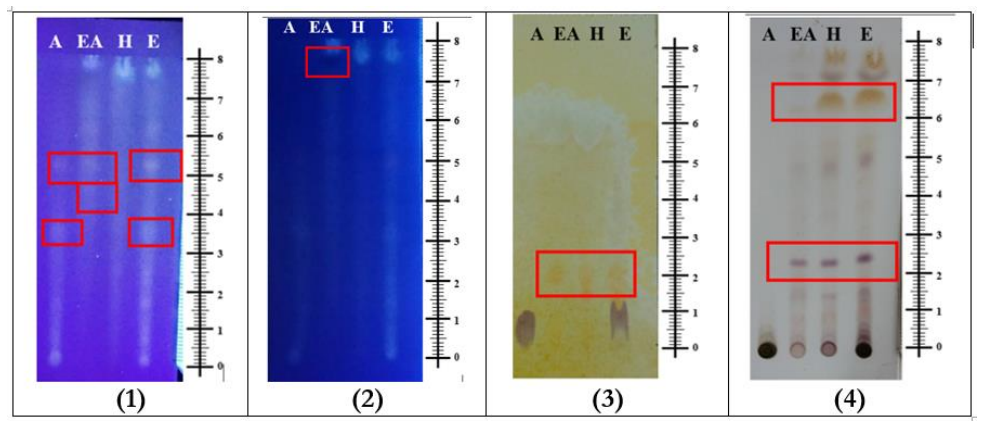

Figure 3. The presence of black spots with $\mathrm{Rf} 0.93$ in visible light observations after spraying $\mathrm{FeCl}_{3}$ reagents. $\mathrm{A}=$ water fraction, $\mathrm{EA}=$ ethyl acetate fraction, $\mathrm{H}=\mathrm{n}$-heksane fraction, $\mathrm{E}=$ ethanolic extract

On the identification of alkaloid group compounds using thin layer chromatography, positive results were obtained on E, $\mathrm{H}$ and EA as shown in Figure 3 no. 3. This can be shown by the presence of orange-colored spots on visible light observations with Rf 0.25 in E, H, and EA after being sprayed with dragendorff reagent.

The identification results of the terpenoid group compounds content can be seen in Figure 3 no. 4. Based on these results, it is known that $\mathrm{E}, \mathrm{H}$, and EA gave positive results. This can be proved by the presence of spots on Rf 0.31 on E and Rf 0.28 in $\mathrm{H}$ and EA where these spots are purple at visible light appearance after spraying Liebermann-Burchard reagent. According to Sharifa et al (2012), terpenoid compounds will form pink color, magenta to purple after spraying Liebermann-Burchard reagent [14]. In visible light appearance of Rf $0.83 \mathrm{E}, 0.81 \mathrm{H}$, and $0.80 \mathrm{EA}$, there are brown spots. This also confirms the positive results of triterpenoid compounds in $\mathrm{E}, \mathrm{H}$, and EA.

Table 2. Bioactive compounds

\begin{tabular}{lcccc}
\hline & Flavonoid & Tanin & Alkaloid & Terpenoid \\
\hline Ethanolic extract & $\checkmark$ & $\times$ & $\checkmark$ & $\checkmark$ \\
n-Heksane fraction & $\times$ & $\times$ & $\checkmark$ & $\checkmark$ \\
Ethyl acetate fraction & $\checkmark$ & $\checkmark$ & $\checkmark$ & $\checkmark$ \\
Water fraction & $\checkmark$ & $\times$ & $\times$ & $\times$ \\
\hline
\end{tabular}

The $\alpha$-amylase inhibitor of the plant can be either protein or non-protein bioactive compound. Non-protein type $\alpha$-amylase inhibitors can be plant compounds such as flavonoids [2,6,7], alkaloids [8], terpenoids [9], and tannins [6]. The all results of bioactive compounds identification in this study shows that ethanolic extract contains flavonoids, alkaloids and 
terpenoids; n-heksane fraction contains alkaloids and terpenoids; ethyl acetate fraction contains flavonoids, tannins, alkaloids and terpenoids; and water fraction contains flavonoids.

The ethyl acetate fraction was the fraction which had the highest $\alpha$-amylase activity compared to the activity of ethanolic extract, n-heksane fraction, and water fraction but it was still less active when compared with acarbose. Based on these results, bioactive compounds that play a dominant role in the inhibitory activity of $\alpha$-amylase from lebui seed are more likely to be tannins. As described in Table 2, these are due to the ethyl acetate fraction contains flavonoids, tannins, alkaloids, and terpenoids, whereas in ethanolic extract, n-heksane fraction, and water fraction there are no tannin compounds.

\section{CONCLUSION}

Based on the results of the research and discussion, it can be concluded that lebui seed has

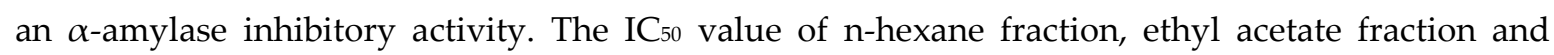
water fraction are $173.0489 \mathrm{mg} / \mathrm{ml}, 9.9878 \mathrm{mg} / \mathrm{ml}$ and $137.1920 \mathrm{mg} / \mathrm{ml}$, respectively The bioactive compounds in n-hexane fraction are alkaloids and terpenoids. While in ethyl acetate fraction are flavonoids, alkaloids, terpenoids, and tannins and in water fraction is flavonoids. Ethyl acetate fraction is supposed to be a fraction that has the highest $\alpha$-amylase inhibition activity in which the possible bioactive compound is tannin.

Acknowledgements : This study was funded by New Zealand Goverment through CaRED project, a collaboration between New Zealand Goverment and Universitas Gadjah Mada.

\section{Reference}

1. Jabir AS and Iraby AG. Studying the Effect of Anti Amylase Inhibitor Extracted from White Kidney Bean (Phaseolus vulgaris) in Treat Diabetes and Obesity in an Affected Mice. International Journal of Current Microbiology and Applied Scinece. 2014, 3(10): 97-106

2. Brahmachari G. Bio-Flavonoids with Promising Antidiabetic Potentials: A Critical Survey. Research Signpost. 2011, 187-212

3. Feng J, Yang XV and Wang RF. Bio-assay Guided Isolation and Identification of $\alpha$-Glucosidase Inhibitor from the Leaves of Aquilaria sinensis. Phytochemistry. 2011, 72: 242-247

4. De Sales, Paloma M, Paula MS, Luiz AS, Perola OM and Damaris S. $\alpha$-Amylase Inhibitors: A Review of Raw Material and Isolated Compound from Plant Source. Journal of Pharmacy and Pharmaceutical Science. 2012, 15(1): 141-183

5. Giri AP and Manvendra K. Amylase Inhibitors of Pigeonpea (Cajanus cajan) seeds. Phytovhemistry. 1998, 47: 197-202

6. Sales PMD, Souza PMD, Simeoni LA, Magalhaes PDO, Silveria D. $\alpha$-Amylase Inhibitors: A Review of Raw Material and Isolated Compounds from Plant Source. Journal of Pharmacy and Pharmaceutical Science. 2012, 15(1): 141-183

7. Hartika R. Aktivitas Inhibisi $\alpha$-Glukosidase Ekstrak Senyawa Golongan Flavonoid Buah Mahkota Dewa (Skripsi). Departemen Kimia, Fakultas Matematika dan Ilmu Pengetahuan Alam, Institut Pertanian Bogor, Bogor. 2009.

8. Samson ZM. Senyawa Golongan Alkaloid Ekstrak Buah Mahkota Dewa sebagai Inhibitor Alfa Glukosidase. (Skripsi). Departemen Kimia, Fakultas Matematika dan Ilmu Pengetahuan Alam, Institut Pertanian Bogor, Bogor. 2010. 
9. Rais, Ichwan R, Agung GS, Sitarina W and Agung EN. Determination of Andrographolide Isolate Activity to $\alpha$-Amylase and $\alpha$-Glucosidase using Apostolidis and Mayur Method. Traditional Journal of Medicine. 2013, 18(3): 162-166

10. Aja PM, Alum EM, Ezeani NN, Nwali BU and Edwin N. Comparative Phytochemical Composition of Cajanus cajan Leaf and Seed. International Journal of Microbiological Research. 2015, 6(1): 42-46.

11. Marliana SD, Suryanti V and Suyono. Skrining Fitokimia dan Analisis Kromatografi Lapis Tipis Komponen Kimia Buah Labu Siam (Sechium edule jacq. Swartz) dalam Ekstrak Etanol. (Skripsi). Universitas Sebelas Maret, Surakarta. 2005

12. Wagner $\mathrm{H}$ and Bladt S. Phytochemical Screening: Plant Drug Analysis, A Thin Layer Chromatography.Atlas. Springer, Berlin. 2001.

13. Banu RH and Nagarajan N. TLC and HPTLC Fingerprinting of Leaf Extracts of Wedelia chinensis (Osbeck) Merrill. Journal of Pharmacognosy and Phytochemistry, 2014, 2(6): 29-33

14. Sharifa AA, Jamaludin J, Kiong LS, Chia LA and Osman K. Anti-Urolithiatic Terpenoid Compound from Plantago Major Linn (Ekor Anjing). Sains Malaysiana. 2012, 41(1): 33-39

15. Robinson and Trevor. Kandungan Organik Tumbuhan Tinggi. Penerbit ITB, Bandung. 1995

16. Markham KR. Cara Mengidentifikasi Flavonoid. Penerjemah : Kosasih Padmawinata. Penerbit ITB, Bandung. 1988

(C) 2020 by the authors. Submitted for possible open access publication under the terms and conditions of the Creative Commons Attribution (CC BY) license (http://creativecommons.org/licenses/by/4.0/). 